\title{
Consistency of two stability analysis methods in potatoes
}

\author{
Consistência de dois métodos de análise de estabilidade em batata
}

\author{
Velci Queiroz de Souza ${ }^{1}$ Arione da Silva Pereira ${ }^{I I}$ Giovani Olegário da Silva \\ Roberto Fritsche Neto ${ }^{\mathrm{I}}$ Antônio Costa de Oliveira ${ }^{\mathrm{I}}$
}

\begin{abstract}
The objective of this research was to compare the consistency of the bi-segmented and AMMI (additive main effects and multiplicative interaction analysis) methods for estimating yield stability in potatoes. Data of ten genotypes evaluated in 34 environments (local, growing season and year combinations) of the Rio Grande do Sul state, Brazil, in 1994 and 1995 were used. Three data sets were analyzed: 34environment data set and two 17-environment data subsets, which were chosen by randomly dividing the total data set. For the 34-environment data set, the models gave similar results in relation to the stable genotypes, but they differed with regard to the unstable genotypes. For the 17-environment data sets, the bi-segmented model showed more consistent results, either between subsets or between these and the total data set. For the AMMI model, only the Santo Amor genotype showed consistency between one of the subsets and the total data set. In this work, the bi-segmented method was shown to be more consistent than the AMMI model.
\end{abstract}

Key words: Solanum tuberosum, $G \times$ E interaction, AMMI model, bi-segmented method.

\section{RESUMO}

O objetivo deste trabalho foi comparar a consistência dos métodos bi-segmentado e AMMI (additive main effects and multiplicative interaction analysis) em análise de estabilidade de ensaios de rendimento de batata. Foram utilizados dados de dez genótipos avaliados em 34 ambientes (combinações de local, período de cultivo e ano) do Rio Grande do Sul, Brasil, em 1994 e 1995. Três conjuntos de dados foram analisados: o conjunto de dados dos 34 ambientes e dois subconjuntos de dados de 17 ambientes, que foram escolhidos pela divisão aleatória do conjunto total de dados. Para o conjunto de dados dos 34 ambientes, os modelos deram resultados semelhantes quanto aos genótipos estáveis, mas divergiram quanto aos instáveis. Para os subconjuntos de dados de 17 ambientes, o modelo bi-segmentado revelou resultados mais consistentes, tanto entre os subconjuntos quanto entre estes e o conjunto total. Para o modelo AMMI, apenas o genótipo Santo Amor mostrou consistência entre um dos subconjuntos e o conjunto total. Neste trabalho, o método bisegmentado mostrou-se mais consistente do que o modelo AMMI.

Palavras-chave: Solanum tuberosum, interação $G \times$ E, modelo AMMI, método bi-segmentado.

\section{INTRODUCTION}

The genotype $\mathrm{x}$ environment interaction ( $\mathrm{G}$ $\mathrm{x} E$ ) is very important for plant breeding, mainly concerning the development of improved and superior genotypes (ALLARD \& BRADSHAW, 1964; EBERHART \& RUSSEL, 1966). The differential response of genotypes to environments makes it difficult to select high yielding and stable genotypes (COOPER \& DELACY, 1994), restricting the recommendation of cultivars to specific regions and locals, where they express their superior genetic potential (KANG \& MAGARI, 1996). In order to minimize these problems, the breeder conducts his trials in as many locations as possible, aiming to evaluate and measure the interaction effect (FARIAS et al., 1996).

To study the $\mathrm{G} \times \mathrm{E}$ interaction and to associate it to genotype stability, several models have been proposed. Among the models recently presented, two stand out. The bi-segmented model, proposed by

'Departamento de Fitotecnia/Fitomelhoramento, Faculdade de Agronomia “Eliseu Maciel” (FAEM), Universidade Federal de Pelotas (UFPEL), Pelotas, RS, Brasil. E-mail: velciq@gmail.com.

IIEmbrapa Clima Temperado, Pelotas, RS, Brasil. E-mail: arione@cpact.embrapa.br 
SILVA \& BARRETO (1985) and modified by CRUZ et al. (1989), and the AMMI model (additive main effects and multiplicative interaction analysis), proposed by ZOBEL et al. (1988) and modified by GAUCH (1993). For the bi-segmented method, the stability is represented by the variance component due to the deviations of regression $\left(\sigma_{d i}^{2}\right)$. The slope of straight lines $\mathrm{B}_{1 \mathrm{i}}$ and $\mathrm{B}_{1 \mathrm{i}}+\mathrm{B}_{2 \mathrm{i}}$ represents the adaptability of genotypes to the more or less favorable environments, respectively. As a bi-segmented regression, the model represents better the performance of genotypes in several environments (CRUZ et al., 1989).

The AMMI model has been used for modeling and better understanding $\mathrm{G} x \mathrm{E}$ interaction (GAUCH, 1988; ZOBEL et al., 1988; GAUCH \& ZOBEL, 1996). For GAUCH \& FURNAS (1991). The best estimator to represent the genotype stability is the first main component (PCA 1). In a previous study, using the same data, PEREIRA \& COSTA (1998) compared the AMMI analysis to the regression analysis, concluding that the AMMI model is more efficient in describing the $\mathrm{G} x \mathrm{E}$ interaction, on the basis of sum of squares of the interaction.

The aim of this study was to compare the consistency of the bi-segmented and AMMI (additive main effects and multiplicative interaction analysis) methods for estimating yield stability in potatoes, using data of ten potato genotypes tested in 34 environment of the Rio Grande do Sul state.

\section{MATERIAL AND METHODS}

Total tuber yield data of ten potato (Solanum tuberosum) genotypes tested in 34 environments (local, growing season and year combinations) of production areas of Rio Grande do Sul state, in 1994 and 1995 was evaluated. The following genotypes were tested: Atlantic, Baronesa, Cristal, Macaca, Monte Bonito, Santo Amor, Trapeira, 2AC917-7-80, C-1226-35-80 and CR-1290-5-82. Atlantic was introduced in Brazil from the United States of America and the other genotypes were developed by the breeding program of Embrapa Clima Temperado. The experimental design was a randomized complete block with four replications and plots consisting of two 25plant rows, spaced in $0.30 \mathrm{~m}$ between plants and $0.80 \mathrm{~m}$ between rows. The cultural practices were the ones used in each region.

The data was submitted to variance analysis (ANOVA). The G x E interaction effects were estimated using the two models: the bi-segmented regression and the additive main effects and multiplicative interaction analysis (AMMI). The first one is a bi-segmented regression in such a way that each genotype is characterized by two regression lines, one representing unfavorable environments $\left(\mathrm{B}_{\mathrm{1i}}\right)$ and the other favorable environments $\left(\mathrm{B}_{1 \mathrm{i}}+\mathrm{B}_{2 \mathrm{i}}\right)(\mathrm{CRUZ}$ et al., 1989). In the AMMI model (ZOBEL et al., 1988), the additive part of the model is estimated by ANOVA and the multiplicative part is estimated by the principal component analysis.

The bi-segmented model is described by CRUZ et al. (1989), as:

$Y_{i j}=B_{0 i}+B_{1 i} X_{j}+B_{2 i} T\left(X_{j}\right)+\delta_{i j}+e_{i j}$ where: $\sigma_{d i}^{2}$ is the observed mean yield of the i-th genotype in the $\mathrm{j}$-th environment; $B_{0 i}$ is the intercept of the regression equation; $B_{1 i}$ is the linear regression coefficient associated with the variable $X_{j} ; B_{2 i}$ is the linear regression coefficient associated with the variable $; \delta_{i j}$ is the deviation of regression; $e_{i j}$ is the error associated with $Y_{i j}$; $X_{j}$ is the environment index defined as $X_{j}=\frac{Y \cdot_{j}}{m}-\frac{Y . .}{m n}$, where $\sum X_{j}=0 ; T\left(X_{j}\right)=0$ if $X_{j} \leq 0 ; T\left(X_{j}\right)=X_{j}-X_{p}$ if $X_{j}>0$, where $X_{P}$ is the favorable environment mean.

The AMMI model is described by GAUCH (1993) as:

$$
Y_{\text {ger }}=\mu+\alpha_{g}+\beta_{e}+\sum_{n} \lambda_{n} \delta_{e n}+\rho_{g e}+\varepsilon_{\text {ger }}
$$

where: $Y_{g e r}$ is the yield of genotype $g$ in the environment $e$ for $r$ replications; $\mu$ is the overall mean; $\alpha_{g}$ is the deviation of the mean of the genotype $g ; \beta_{e}$ is the deviation of the mean of the environment $e ; \lambda_{n}$ is the eigenvalue of the principal component axis, $n ; Y_{g n}$ is the eigenvalue of the genotype $g$ for the axis of principal components $n ; \delta_{e n}$ is the eigenvalue of the environment $e$ for the axis of the principal components $n$; is the residue of the interaction; is the error associated to $Y_{\text {ger }}$.

The ANOVA was used to verify the significance of the interaction $\mathrm{G} x \mathrm{E}$, whereas the models were applied to estimate the interaction. The effects of genotypes were considered fix and the effects of environment random.

For the bi-segmented analysis, GENES 2001.0 software (CRUZ, 2001) was applied, and for the AMMI analysis, the MATMODEL, version 2.0 (GAUCH, 1993) was used.

The analysis of the $\mathrm{G} x \mathrm{E}$ interaction was performed on the 34-environment data set to estimate the stability of genotypes by the two models. The data of the two 17-environment data subsets were taken by randomly dividing the 34-environment data set. The three data sets (total and two subsets) were analyzed to compare the consistency of the two models. 


\section{RESULTS}

The analysis of variance (ANOVA) of the 34-environment data set showed significance $(\mathrm{P} \leq 0,05)$ for genotypes, environments and $\mathrm{G} x \mathrm{E}$ interaction (Table 1). Also, the ANOVA of the two 17-environment data subsets revealed significance for all factors of variation, including the $\mathrm{G} \times \mathrm{E}$ interaction (Table 2).

For both models, bi-segmented $\left(\sigma_{d i}^{2}\right)$ and AMMI (PCA 1), Santo Amor and Trapeira showed to be the most stable genotypes for the 34-environment data set (Table 3). Monte Bonito and CR-1290-5-82 were the most unstable genotypes for the bi-segmented model, whereas Macaca and Cristal were the most unstable ones for the AMMI model, as previously reported (PEREIRA \& COSTA, 1998).

The results of the stability analysis of the two 17-environment data subsets showed differences between the two models (Table 3). For the bi-segmented model, the two data subsets had similar results. Santo Amor and Trapeira were the most stable genotypes, except that they were inversely classified in the subsets. CR-1290-5-82, Monte Bonito and Macaca were the most unstable genotypes in both data subsets.

Correlation coefficients of stability values for the 34-environment data set, estimated by the AMMI model, with stability values for the 17environment data subsets 1 and 2, calculated by the bi-segmented model, were high $(\mathrm{r}=0.77$ and 0.73 , respectively) (Table 4). Within the AMMI model estimates, correlations between the estimates for 34environment data set and for the two 17-environment data subsets, and between estimates for the two data subsets were very low and not significant. The correlation coefficient between the two models for the 34-environment data set was high and significant $(\mathrm{r}=$ 0.79). The bi-segmented model estimates for the 34environment data set was very highly correlated with the estimates for the data subsets 1 and 2 ( $r=0.99$ and 0.97 , respectively).

\section{DISCUSSION}

High and stable yield is one of the main objectives of potato breeding programs, besides good quality and resistance to the main diseases. Differential responses of genotypes to variation in environments make selection difficult (PEREIRA \& COSTA, 1998). Many studies have been reported on methods to estimate the stability of genotypes and environments (FINLAY \& WILKINSON, 1963; EBERHART \& RUSSEL, 1966; TAI, 1971; GAUCH \& ZOBEL, 1989; GAUCH \& FURNAS, 1991; SILVA, 1995a/b), but the interest continues into looking for models that reliably and precisely estimate stability parameters.

In this work, the analysis of bi-segmented and AMMI models resulted in different stability estimates (Table 3). The parameters estimated for the 34-environment data set by the bi-segmented and the AMMI models were high and positively correlated (Table 4.). Santo Amor and Trapeira, were the most stable genotypes, regardless of the models used. Since the correlation was not perfect, the ranking of genotypes differed, explaining the difference in relation to the most stable genotypes.

Considering the results of the analysis of the two 17-environment subsets, the bi-segmented model showed more consistency than the AMMI model in classifying the genotypes for stability. In the bisegmented model, correlation coefficients between the stability estimates of the total data set and the two data subsets were close to 1 , showing consistency of the results.

Regression deviations were low for the total data set as well as for the two data subsets. High regression deviations can be considered as an indication of inadequacy of the linear model postulated to represent the relation between yield and the environment index (SILVA, 1995b). Therefore, regression can be used, but with caution for evaluation

Table 1 - Mean squares for the analysis of variance of total tuber yield data ( $\mathrm{t} \mathrm{ha}^{-1}$ ) of ten potato genotypes in 34-environments (local, growing season and year combinations) of the Rio Grande do Sul state.

\begin{tabular}{|c|c|c|c|c|c|}
\hline Sources of variation & Degree of freedom & Sum of squares & Mean square & $\mathrm{F}$ & $\mathrm{P} \leq \mathrm{F}$ \\
\hline Blocks/environment & 102 & $3,719.243$ & 36.463 & & \\
\hline Genotypes (G) & 9 & $10,018.095$ & $1,113.122$ & 103.220 & $<0.001$ \\
\hline Environments (E) & 33 & $129,020.891$ & 3,909.724 & 107.224 & $<0.001$ \\
\hline$G \times E$ & 297 & $22,688.833$ & 76.393 & 7.084 & $<0.001$ \\
\hline Error & 918 & $9,899.718$ & 10.784 & & \\
\hline Total & 1.359 & $175,346.779$ & & & \\
\hline General mean & 22.35 & & & & \\
\hline $\mathrm{CV}(\%)$ & 14.69 & & & & \\
\hline
\end{tabular}


Table 2 - Mean squares for the analysis of variance of total tuber yield ( $\mathrm{t} \mathrm{ha}^{-1}$ ) of ten potato genotypes for two subsets of 17-environments randomly chosen from the set of 34-environments (local, growing season and year combinations) of the Rio Grande do Sul state.

\begin{tabular}{|c|c|c|c|c|c|}
\hline \multirow{2}{*}{ Sources of variation } & \multirow{2}{*}{ Degree of freedom } & \multicolumn{2}{|c|}{ Subset 1} & \multicolumn{2}{|c|}{ Subset 2} \\
\hline & & Mean square & $\mathrm{P} \leq \mathrm{F}$ & Mean square & $\mathrm{P} \leq \mathrm{F}$ \\
\hline Blocks/environment & 51 & 18.630 & & 54.296 & \\
\hline Genotypes (G) & 9 & 799.607 & $<0.001$ & 390.126 & $<0.001$ \\
\hline Environments (E) & 16 & $5,193.506$ & $<0.001$ & $2,287.384$ & $<0.001$ \\
\hline $\mathrm{G} \times \mathrm{E}$ & 144 & 83.054 & $<0.001$ & 69.720 & $<0.001$ \\
\hline Error & 459 & \multicolumn{2}{|c|}{9.918} & \multicolumn{2}{|c|}{11.650} \\
\hline General mean & & \multicolumn{2}{|c|}{24.97} & \multicolumn{2}{|c|}{19.73} \\
\hline $\mathrm{CV}(\%)$ & & \multicolumn{2}{|c|}{12.61} & \multicolumn{2}{|c|}{17.30} \\
\hline
\end{tabular}

of the phenotypic stability, since the bi-segmented linear regression analysis can fail as any statistical modeling technique, but it constitutes an additional tool that breeders can use for selection (SILVA, 1995b).

In the AMMI analysis, there was some inconsistency of stability of the genotypes in the two data subsets. In the data subset 1, Atlantic and 2AC917-7-80 were the most stable genotypes and Santo Amor and CR-1290-5-82 were the most unstable. On the other hand, in the data subset 2, 2AC-917-7-80 and Santo Amor showed to be the most stable genotypes, and Trapeira and Baronesa the most unstable. Compared to the 34-environment data set, the most stable and the unstable genotypes for the data subset 1 did not match. In fact, there was a change in the classification of Santo Amor from stable to unstable.
In the data subset 2, only Santo Amor was stable, coinciding with the estimation of the total environment data set.

Correlation coefficients between estimations of the models and data set combinations indicate consistency of two stability methods (Tables 4). Therefore, the AMMI model gave less consistent estimates than the bi-segmented analysis. It may be a result of the low representation of the sum of squares of the principal components, which should be grouped, in a higher number of components to truly represent the stability of the genotypes. The percentage of sum of square for treatments must be explained by $80-95 \%$ of the sum of squares of the first principal component - genotype, environment and interaction (GAUCH \&

Table 3 - Stability parameters for total yield of ten potato genotypes estimated by the bi-segmented model ( $\sigma_{d i}^{2}$ ), and by the AMMI model (PCA 1), for the 34-environment (local, growing season and year combinations) data set and for two randomly chosen 17environment data subsets.

\begin{tabular}{|c|c|c|c|c|c|c|}
\hline \multirow{2}{*}{ Genotype } & \multicolumn{3}{|c|}{$\sigma_{d i}^{2}$} & \multicolumn{3}{|c|}{ PCA 1} \\
\hline & Set & Subset 1 & Subset 2 & Set & Subset 1 & Subset 2 \\
\hline Santo Amor & 0.594 & 0.288 & 1.490 & 5.328 & -220.137 & 12.692 \\
\hline Trapeira & 1.359 & 1.549 & 0.964 & -13.682 & 70.900 & -147.792 \\
\hline Baronesa & $2.299 *$ & $3.100 *$ & $2.069 *$ & -34.592 & 75.375 & 119.521 \\
\hline $2^{A} C-917-7-80$ & $2.813^{*}$ & $3.623^{*}$ & $2.442 *$ & 32.340 & -2.048 & 8.017 \\
\hline Cristal & $3.437^{*}$ & $3.698 *$ & $2.028 *$ & -119.710 & 55.362 & 70.204 \\
\hline C-1226-35-80 & $4.701^{*}$ & $5.701 *$ & $3.705^{*}$ & 30.616 & 75.125 & -24.368 \\
\hline Atlantic & $7.269 *$ & $7.351 *$ & 8.795* & 63.661 & 1.673 & -17.983 \\
\hline Мacaca & 9.163* & $7.828 *$ & $9.572^{*}$ & -120.392 & -71.898 & -94.866 \\
\hline Monte Bonito & $10.377^{*}$ & $9.692 *$ & $9.089 *$ & 104.638 & 82.247 & 18.325 \\
\hline CR-1290-5-82 & $11.627^{*}$ & $10.118^{*}$ & $13.612^{*}$ & 51.738 & 83.651 & 56.250 \\
\hline \multicolumn{4}{|c|}{ Percentage of the sum of squares of the $\mathrm{G} x \mathrm{E}$ interaction } & 44.60 & 60.0 & 43.58 \\
\hline
\end{tabular}

*Values different from zero by the t test at $5 \%$ significance. 
Table 4 - Simple correlation coefficients between stability values estimated by the bi-segmented model ( $\left.\sigma_{d i}^{2}\right)$, and by the AMMI model (PCA 1), for the 34-environment (local, growing season and year combinations) data set and for two randomly chosen 17environment data subsets of total tuber yield of ten potato genotypes, in the Rio Grande do Sul state.

\begin{tabular}{|c|c|c|c|c|c|}
\hline Model - Data & AMMI Set & Bi-seg. Subset 1 & Bi-seg. Subset 2 & AMMI Subset 1 & AMMI Subset 2 \\
\hline Bi-Seg. - Set & $0.79^{*}$ & $0.99^{* *}$ & $0.97^{* *}$ & $-0.29^{\text {ns }}$ & $-0.20^{\text {ns }}$ \\
\hline AMMI - Set & & $0.77^{*}$ & $0.73^{*}$ & $-0.15^{\mathrm{ns}}$ & $0.03^{\mathrm{ns}}$ \\
\hline Bi-Seg. - Subset 1 & & & $0.93^{* *}$ & $-0.37^{\text {ns }}$ & $-0.23^{\text {ns }}$ \\
\hline Bi-seg. - Subset 2 & & & & $-0.17^{\mathrm{ns}}$ & $-0.24^{\mathrm{ns}}$ \\
\hline AMMI - Subset 1 & & & & & $-0.04^{\mathrm{ns}}$ \\
\hline AMMI - Subset 2 & & & & & \\
\hline
\end{tabular}

* and ** significant at 0.05 and 0.01 probability levels by test t, respectively.

${ }^{\mathrm{ns}}$ Not significant $(\mathrm{P}>0.05)$.

FURNAS, 1991), since $90 \%$ of the treatment sum of squares captures almost all real information of the data. According to these authors, the AMMI model is highly informative when both, the principal effects and the interaction, are significant, which is commonly observed in field experiments.

In the previous study (PEREIRA \& COSTA, 1998), although the AMMI analysis had been more efficient in describing the $\mathrm{G} x \mathrm{E}$ interaction than the linear regression technique, the percentage of sum of squares explained by the first principal component was only 44,6\%. Therefore, it might explain the lower consistency of the AMMI model than the bi-segmented method in estimating stability parameters.

Although both methods have identified Santo Amor and Trapeira, as the most stable genotypes, the bi-segmented method was shown to be more consistent than the AMMI model in estimating yield stability of potatoes.

\section{ACKNOWLEDGEMENTS}

The authors acknowledge the support team of the potato breeding program of Embrapa Clima Temperado; the fellow students and professors of the Departamento de Fitotecnia of the Faculdade de Agronomia 'Eliseu Maciel'; the Coordenação de Aperfeiçoamento de Pessoal de Nível Superior (CAPES), the Conselho Nacional de Desenvolvimento Científico e Tecnológico (CNPq), and the Fundação de Amparo à Pesquisa do Estado do Rio Grande do Sul (FAPERGS) for scholarships.

\section{REFERENCES}

ALLARD, R.W.; BRADSHAW, A.D. Implications of genotypeenvironment interactions in applied plant breeding. Crop Science, Madison, v.4, n.5, p.503-508, 1964.

COOPER, M.; DELACY, I.H. Relationships among analytical methods used to study genotypic variation and genotype-by- environment interaction in plant breeding multi-environment experiments. Theoretical Applied of Genetics, New York, v.88, n.5, p.561-572, 1994.

CRUZ, C.D. Programa genes - versão windows 2001.0.0. Viçosa: UFV, 2001. 642p.

CRUZ, C.D. et al. An alternative approach to the stability analysis proposed by Silva and Barreto. Revista Brasileira de Genética, Ribeirão Preto, v.12, n.2, p.567-580, 1989.

EBERHART, S.A.; RUSSEL, W.A. Stability parameters for comparing varieties. Crop Science, Madison, v.6, n.1, p.3640, 1966.

FARIAS, F.J.C. et al. Parâmetros de estabilidade em cultivares de algodoeiro herbáceo avaliadas na região nordeste do Brasil. Pesquisa Agropecuária Brasileira, Brasília, v.31, p.877883, 1996.

FINLAY, K.W.; WILKINSON, G.N. The analysis of adaptation in a plant breeding programme. Australian Journal of Agricultural Research, Victoria, v.14, p.742-754, 1963.

GAUCH, H.G. MATMODEL, Versão 2.0: AMMI and related analysis for two-way data matrices. Ithaca: Microcomputer Power, 1993. 59p.

GAUCH, H.G. Model selection and validation for yield trials with interaction. Biometrics, Washington, v.44, n.3, p.705715, 1988.

GAUCH, H.G.; FURNAS, R.E. Statistical analysis of yield trial with MATMODEL. Agronomy Journal, Madison, v.83, n.5, p.916-920, 1991.

GAUCH, H.G.; ZOBEL, R.W. Accuracy and selection success in yield trial analysis. Theoretical Applied of Genetics, New York, v.77, n.4, p.473-481, 1989.

GAUCH, H.G.; ZOBEL, R.W. AMMI analysis of yield trials. In: KANG, M.S.; GAUCH, H.G. (Eds). Genotype by environment interaction. Boca Raton: CRC, 1996. p.85-122.

Ciência Rural, v.37, n.3, mai-jun, 2007. 
KANG, M.S.; MAGARI, R. New development in selection for phenotypic stability in crop breeding. In: KANG, MS; GAUCH, H.G. (Eds). Genotype by environment interaction. Воса Raton: CRC, 1996. p.1-14.

PEREIRA, A.S.; COSTA, D.M. Análise de estabilidade de produção de genótipos de batata no Rio Grande de Sul. Pesquisa Agropecuária Brasileira, Brasília, v.33, n.4, p.405-409, 1998.

SILVA, J.G.C. Análise da adaptabilidade através de regressão linear segmentada: I Fundamentos. Pesquisa Agropecuária Brasileira, Brasília, v.30, n.4, p.435-448, 1995a.
SILVA, J.G.C. Análise da adaptabilidade através de regressão linear segmentada: II Aplicação. Pesquisa Agropecuária Brasileira, Brasília, v.30, n.4, p.449-462, 1995b.

SILVA, J.G.C.; BARRETO, J.N. Application of segmented linear regression to the study of genotype $\mathrm{x}$ environment interaction. Biometrics, Washington, v.41, n.4, p.1093, 1985.

TAI, G.C.C. Genotypic stability analysis and application to potato regional trials. Crop Science, Madison, v.11, n.2, p.184-190, 1971

ZOBEL, R.W. et al. Statistical analysis of a yield trial. Agronomy Journal, Madison, v.80, n.3, p.388-393, 1988. 